\title{
Model of price-dependent management of an industrial enterprise energy consumption
}

\author{
I.A. Solovieva ${ }^{1}$, and A.P. Dzyuba ${ }^{1, *}$ \\ ${ }^{1}$ South Ural State University, Chelyabinsk, Russia
}

\begin{abstract}
The article is devoted to the problems of price-dependent management of energy consumed by industrial enterprises which are involved in purchasing energy in the wholesale and retail energy markets. The article provides the analysis of forming the obligation value to pay for each component of cost of energy. There have been revealed ways and time intervals of energy consumption demand value management in order to minimize the obligation value to pay for cost of energy. The authors have developed a model aimed at managing energy consumption demand which takes into consideration the specific character of forming the obligation to pay in terms of each component of cost bearing in mind to the factors restricting possibilities to manage demand in the time intervals required. The article also covers some description of the parameters developed for information support of the model offered. The practical approval conducted by the authors, permits to state that using the mechanism of price-dependent energy consumption gives industrial enterprises substantial reserves to reduce energy consumption costs. The research results are of practical importance and can be applied in everyday activity connected with energy purchasing by industrial enterprises.
\end{abstract}

\section{Introduction}

One of the most vital ways to improve industrial enterprises production efficiency is to reduce the share and value of costs incurred due to electric energy and power consumption which is dominated by electric energy. All the electric energy within the framework of the Russian economy, as well as in most countries of the world, is sold and bought in the energy markets which are characterized by the fact that buyers can regulate the price of the energy bought. One of the underexamined ways in this area is price-dependent energy consumption management.

The domain of price-dependent energy consumption management is researched mostly by American and European scientists [1-6]. A great part of the research data deal with the concept and policy elaboration aimed at encouraging final users to cut down demand schedules of their own. Among the national researchers it's Professor Gitelman L.D. whose contribution in development of energy consumption management is the greatest [7-9]. His works are devoted to the problems of adjustment of foreign experience in consumption management mechanisms to Russian energy markets.

However, among both national and foreign researches one fails to find a work concerned with development of models to manage energy consumption demand schedule of end energy consumers, adjusted to contemporary energy markets.

\section{Methodology of research}

Price-dependent energy consumption is a model to flexibly manage energy consumption demand of your own based on being responsive to price signals of the energy market to minimize energy consumption costs.

The peculiar feature of price-dependent energy consumption management at industrial enterprises is the possibility to reduce energy consumption costs without cutting down the production plan numbers. Economic effect is achieved due to economically viable rescheduling curves of operational processes and electrical energy demand connected with them [10].

Cost of energy for industrial enterprises of Russia is made up of three basic structural components: electric energy, electric power and electric power transmission.

Figure 1 shows an aggregate structure of electric energy cost for industrial enterprises of Russia.

The value of electric energy and electric power is formed by competitive pricing mechanism while electric energy transmission value depends on regulated price performance $[11,12]$.

In case industrial enterprises have little influence on price in the energy market, their own values of energy demand schedules can be managed directly through regulating regimes of operational processes and scheduling working hours for equipment consuming much energy.

From our standpoint, all the above components of electric energy cost are subject to management using price-

Corresponding author: dzyuba-a@yandex.ru 
dependent mechanisms making it possible for the consumers to lower costs when buying energy.

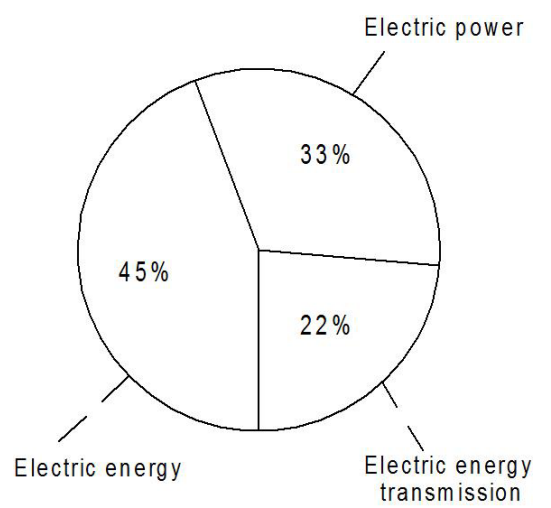

Fig. 1. Structure of electric energy cost for industrial enterprises of Russia.

\section{Component "electric energy"}

The obligation to pay for electric energy, electric power and electric energy transmission services for each enterprise is calculated individually based on the hourly schedule of energy consumption during the billing month. At that the methods used to calculate the obligation value to pay for each component have principles, rules and peculiarities of their own. The obligation value to pay for electric energy is calculated by multiplying tomorrow market hourly prices by corresponding hourly energy consumption volumes. Tomorrow market hourly prices are exemplified in Figure 2. As can be seen from the figure, tomorrow market prices which are formed for every hour are characterized by substantial diurnal volatility.

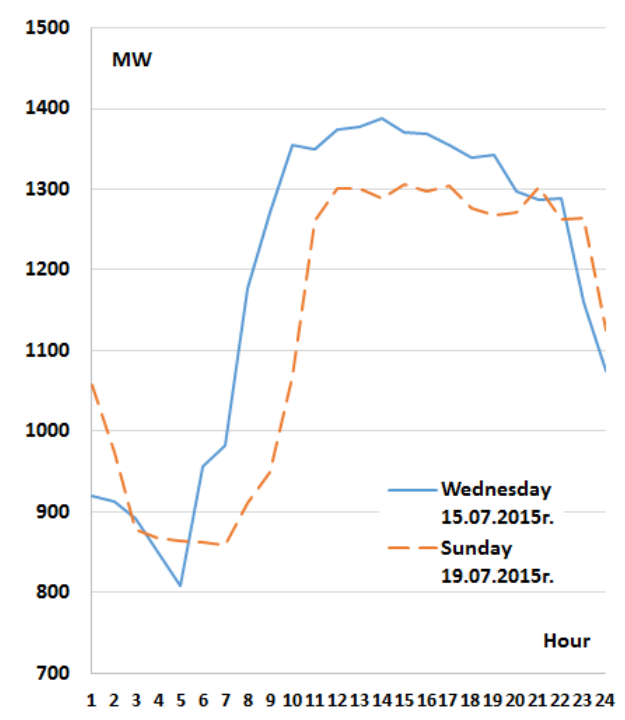

Fig. 2. An example of diurnal hourly curves of tomorrow market prices for a work day and a day off in July, 2016 [13].

Prices at peak hour of working day may be twice as big as post-meridiem prices.

Tomorrow market prices may differ depending on whether it's a work day or a weekend, amounting up to twofold differences.
We consider that price-dependent management of hourly demand schedule must mean channeling energy consumption demand from the time intervals characterized by the highest energy consumption price to economically beneficial periods. It'll allow industrial enterprises to reduce costs of buying electric energy up to $50 \%$.

The periods for price-dependent management of hourly electric energy demand are necessary to be identified with the help of forecasting of the parameters of tomorrow market prices $[14,15]$.

Component "electric energy" costs are calculated using formula (1) and effect of price-dependent energy consumption management is the difference between the price of electric energy before and after managing energy demand schedule (formula 2).

$$
S W_{m}=\sum_{m}\left(W^{t} \times P_{P C B}^{t}\right)+\sum_{m} P_{B P}
$$

$S W_{m}$ - value of electric energy bought by the industrial enterprise in $\mathrm{m}$ month,

$W^{t}-$ industrial enterprise electric energy consumption per hour t,

$P_{P C B}^{t}$ - tomorrow market price (PCB) per hour $\mathrm{t}$,

$\sum_{m} P_{5 P}$ - value of buying electric energy in the balancing sector of the wholesale energy market.

$\sum_{m} P_{5 P}-$ is considered provided electric energy is bought within the wholesale energy market or when buying electric energy in the retail market 5 and 6 price categories are chosen. The authors devoted the series of works [14-16] to researching into electric energy consumption management in $\sum_{m} \bigcup_{D P}$ sector.

$$
\Delta S W_{m}=S W_{m}-S W_{m}^{\prime}
$$

where $\Delta S W_{m}-$ cost saving in terms of electric energy payment resulting from price-dependent energy consumption management,

$S W_{m}$ - costs incurred due to electric energy payment before applying price-dependent energy consumption management,

$S W_{m}^{\prime}$ - costs of electric energy payment after managing price-dependent energy consumption.

\section{Component "electric power"}

The obligation to pay for electric power is formed for every calendar month using hourly electric energy demand schedule for every participant. It is calculated as the mean value of power consumed by the industrial enterprise during the hours which coincide with peak hours of working day of the regional power system during working days of the billing month. The on-peak hours of the regional power system are limited by the peak load planned. Figure 3 shows an example of forming the obligation value to pay for electric power for an industrial enterprise.

Figure 3 demonstrates that the factor upon which the obligation value to pay for buying electric power depends is rather the peak hour of working day of the regional power 
system than daily electric power consumption maximum of the electric energy end user. The hour of the power system daily maximum is determined only for the working days of the billing month and always happens to coincide with one of the planned hours of peak ratings (Fig. 4).

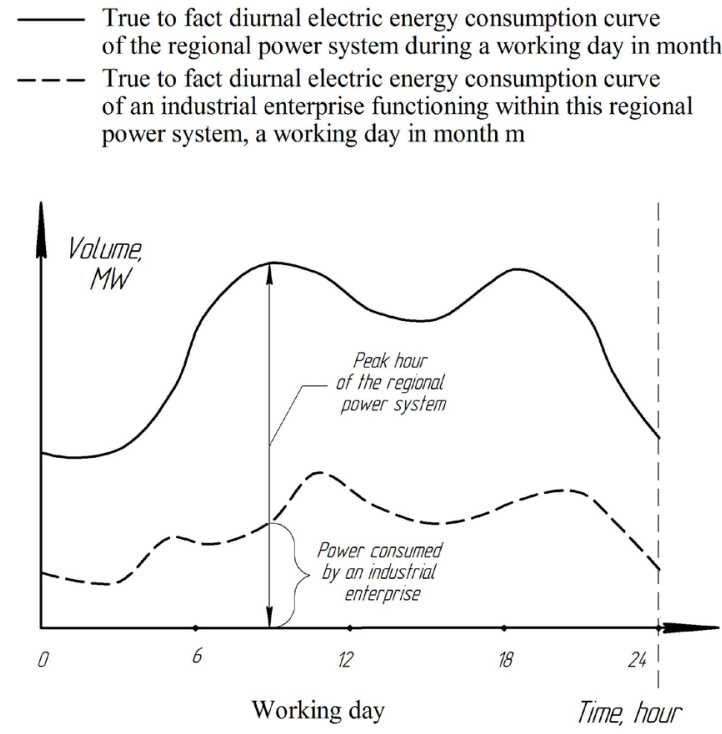

Fig. 3. An example of forming the obligation value to pay for buying electric power by an industrial enterprise [17].

Thus, to reduce the obligation to pay for electric power an industrial enterprise needs to shift peaks of energy demand of their own to the hours which coincide neither with planned peak-load time nor with peak hour of working day of the regional power system.

Forecasting of peak hour of working day of the regional power system can be based on its retrospective data for the last several years, the degree of probability being high enough [19-22]. The approach offered provides industrial enterprises with the tool to lower costs incurred due to purchasing electric power by $10 \%-80 \%$. Costs in terms of component "electric power" can be calculated using formula (3), while the effect which results from pricedependent management mechanism implementation is determined with the help of formula (5).

$$
S P_{m}=V P_{m} \times T P_{m}
$$

$S P_{m}$ - value of power bought by the industrial enterprise in month $\mathrm{m}$,

$T P_{m}$ - price of power bought by the industrial enterprise in month $\mathrm{m}$,

$V P_{m}$ - industrial enterprise obligation value to buy power in month $\mathrm{m}$.

$$
V P_{m}=\sum_{\text {work }, m} W_{t_{-} \text {max_reion }}^{t} / n_{\text {work }, m}
$$

where $t=t$ _max_region .

$W^{t}$ - mount of electric energy consumed by the industrial enterprise during hour $\mathrm{t}$,

t_max_region - hour of coincidental peaking at peak for the Russian Federation entity where the industrial enterprise buys electric energy at hour $\mathrm{t}$ during a working day of month m,

$n_{\text {work, } m}$ - number of working days in month $\mathrm{m}$.

t_max_region $\in T_{-}$peak_SOT_nuk_SO - intervals of planned peak-load time, approved by UES System Operator of Russia.

$$
\Delta S P_{m}=S P_{m}-S P_{m}^{\prime}
$$

where $\Delta S P_{m}$ - cost saving in terms of payment for electric power value as a result of price-dependent management of electric energy consumption,

$S P_{m}$ - costs incurred due to paying for electric power value prior employing price-dependent management of electric energy consumption,

$S P_{m}^{\prime}$ - costs incurred due to paying for electric power value after employing price-dependent management of electric energy consumption.

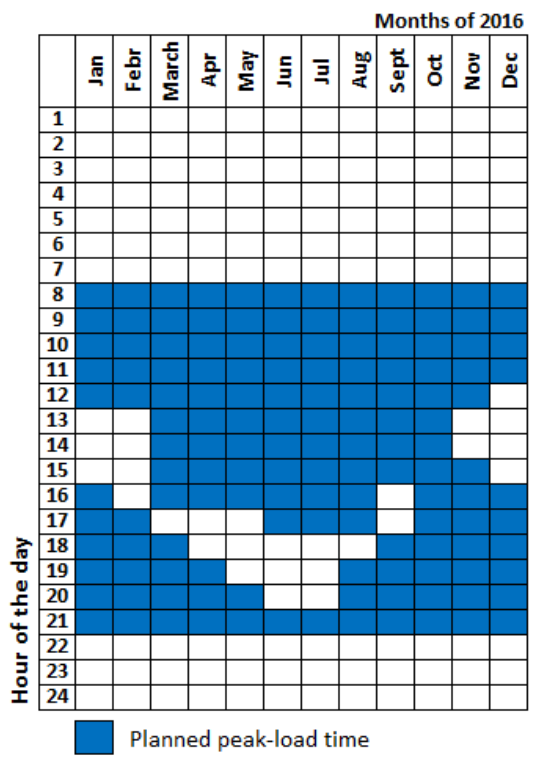

Fig. 4. Chart of peak-load time by months, 2016 [18].

\section{Component "transmission services"}

The amount of obligation to pay for transmission services is formed for every calendar month. The value of electric energy transmission services can be managed only in case the industrial enterprise chooses the two-part tariffs to transmit electric energy, which consists of two components: the value of electric grids utilization and that of technological power requirements [23]. The value of technological power requirements doesn't depend on the shape of hourly load curves and its share in the total value of services on transmission does not exceed $20 \%$.

The value of electric grids utilization is determined based on the hourly graph of electric energy consumption for the billing month for every participant as the mean value of hourly electric energy maximum consumed by the enterprise during planned peak hours of working day (Fig. 4).

Figure 5 depicts an example of forming the industrial enterprise obligation to pay for electric grids utilization. As 
it is seen from the figure the management range can be limited to "the blue zone" hours of working days.

Price-dependent management of electric energy hourly demand schedule must involve energy consumption flattering during the intervals of planned peak-load hours. It is worth mentioning that consumers do know these planned peak-load hours a year ahead. Price-dependent management will let industrial enterprises smooth their own energy peak loads and reduce the amount of obligations to pay for electric energy transmission services. The component "transmission services" costs can be calculated using formulas (6-9), while the effect produced due to implementation of price-dependent management is determined with the help of formula (10).

$$
S \Pi 2_{m}=S \Pi 2_{m}^{\text {Util }}+S \Pi 2_{m}^{\text {Loss }}
$$

$S \Pi 2_{m}$ - transmission services value for an industrial enterprise using the two-part tariff in month $\mathrm{m}$,

$S \Pi 2_{m}^{\text {Util }}$ - transmission services value according to the twopart tariff taking into account electric grids utilization value in month $\mathrm{m},(\mathrm{kW} \times$ month $)$,

$S \Pi 2_{m}^{\text {Loss }}$ - transmission services value according to the two-part tariff considering process losses in electric grids in month $\mathrm{m},(\mathrm{kW} \times$ hour $)(7)$.

$$
S \Pi 2_{m}^{U t i l}=T_{m}^{U t i l} \times V \Pi 2_{m}
$$

$T_{m}^{\text {Util }}$ - rate of tariff for electric grids utilization in month $\mathrm{m}$, $V \Pi 2_{m}$ - value upon which to calculate obligation to pay for electric grids utilization in month $\mathrm{m}(8)$.

$$
V \Pi 2_{m}=\sum_{\text {work }, m} \max \left(W_{T_{-} \text {peak }}^{t} \text { SO }\right) / n_{\text {work }, m}
$$

$\max \left(W_{T_{-} \text {peak_so }}^{t}\right) \quad$ - maximum value of energy consumption during the intervals of planned peak-load hours T_peak_SO, which areapproved by UES System Operator, for working day of the month m (Fig. 4) (9).

$$
S \Pi 2_{m}^{\text {Loss }}=T_{m}^{\text {Loss }} \times \sum_{m} W
$$

$T_{m}^{\text {Loss }}$ - rate of tariff to pay for process losses in electric grids in month $\mathrm{m}$,

$\sum_{m} W$ - total volume of monthly electric energy consumption for billing calendar month (10).

$$
\Delta S \Pi 2_{m}=S \Pi 2_{m}-S \Pi 2_{m}^{\prime}
$$

where $-S \Pi 2_{m}$ costs saving in terms of electric energy transmission services payment due to price-dependent energy consumption management,

$S \Pi 2_{m}$ - costs incurred by paying for electric energy transmission services before applying price-dependent energy consumption management,
$S \Pi 2_{m}^{\prime}$ - costs incurred by paying for electric energy transmission services after price-dependent energy consumption management was exercised.

Thus, it was revealed that all the three components of electric energy value are dependent on the characteristic of the diurnal hourly curve of energy consumption and subject to price-dependent management (11).

$$
S_{m}=\left(S P_{m}+S W_{m}+S \Pi_{m}\right)=f\left(W_{t}\right)
$$

However, shift in one component cost, as a rule, entails changes in the other two components. This fact should be considered while optimizing the hourly schedule of electric energy loads and making managerial decisions.

\section{Actual use experience}

Based on the developed approach to managing costs incurred due to purchasing electric energy, as far as each component is concerned, the model of price-dependent electric energy consumption management at an industrial enterprise was worked out (Fig. 6).

From our viewpoint, the parameters of pricedependent electric energy consumption management should be calculated based not on electric energy consumption parameters and market signals alone, limitations caused by technological and economic possibility of production processes management having an impact on daily hourly load curve shape should also be taken into account. The developed model of price-dependent enterprise electric energy consumption management should be employed when a sizable body of data is available. It leads to tough requirements to providing information for the approach offered. One of the key requirements to the information is its high discreteness. In Table 1there

\begin{tabular}{|c|c|c|}
\hline № & Parameters & $\begin{array}{c}\text { Data discreteness, } \\
\text { analysis depth }\end{array}$ \\
\hline 1 & $\begin{array}{c}\text { Actual electric } \\
\text { energy consumption }\end{array}$ & $\begin{array}{l}\text { Hourly discreteness. On- } \\
\text { line analysis }\end{array}$ \\
\hline 2 & $\begin{array}{l}\text { Planned electric } \\
\text { energy consumption }\end{array}$ & $\begin{array}{l}\text { Hourly discreteness. } \\
\text { Values for 1-30 days } \\
\text { ahead } \\
\end{array}$ \\
\hline 3 & $\begin{array}{l}\text { Planned tomorrow } \\
\text { market price values }\end{array}$ & $\begin{array}{c}\text { Hourly discreteness. } \\
\text { Values for 1-30 days } \\
\text { ahead }\end{array}$ \\
\hline 4 & $\begin{array}{l}\text { Planned peak hours } \\
\text { of working day of } \\
\text { the regional power } \\
\text { system } \\
\end{array}$ & $\begin{array}{l}1 \text { hour per } 1 \text { day. Values } \\
\text { for } 1-30 \text { days ahead }\end{array}$ \\
\hline 5 & $\begin{array}{l}\text { Real peak hours of } \\
\text { working day of the } \\
\text { regional power } \\
\text { system }\end{array}$ & 1 hour per 1 day. \\
\hline 6 & $\begin{array}{l}\text { Planned peak load } \\
\text { time intervals }\end{array}$ & $\begin{array}{c}\text { Interval for every day for } \\
30 \text { days ahead }\end{array}$ \\
\hline
\end{tabular}
are given requirements, worked out by the authors, to volume and discreteness of information necessary for the model to be made use of.

Table 1. Information support data for the model of pricedependent electric energy consumption management. 


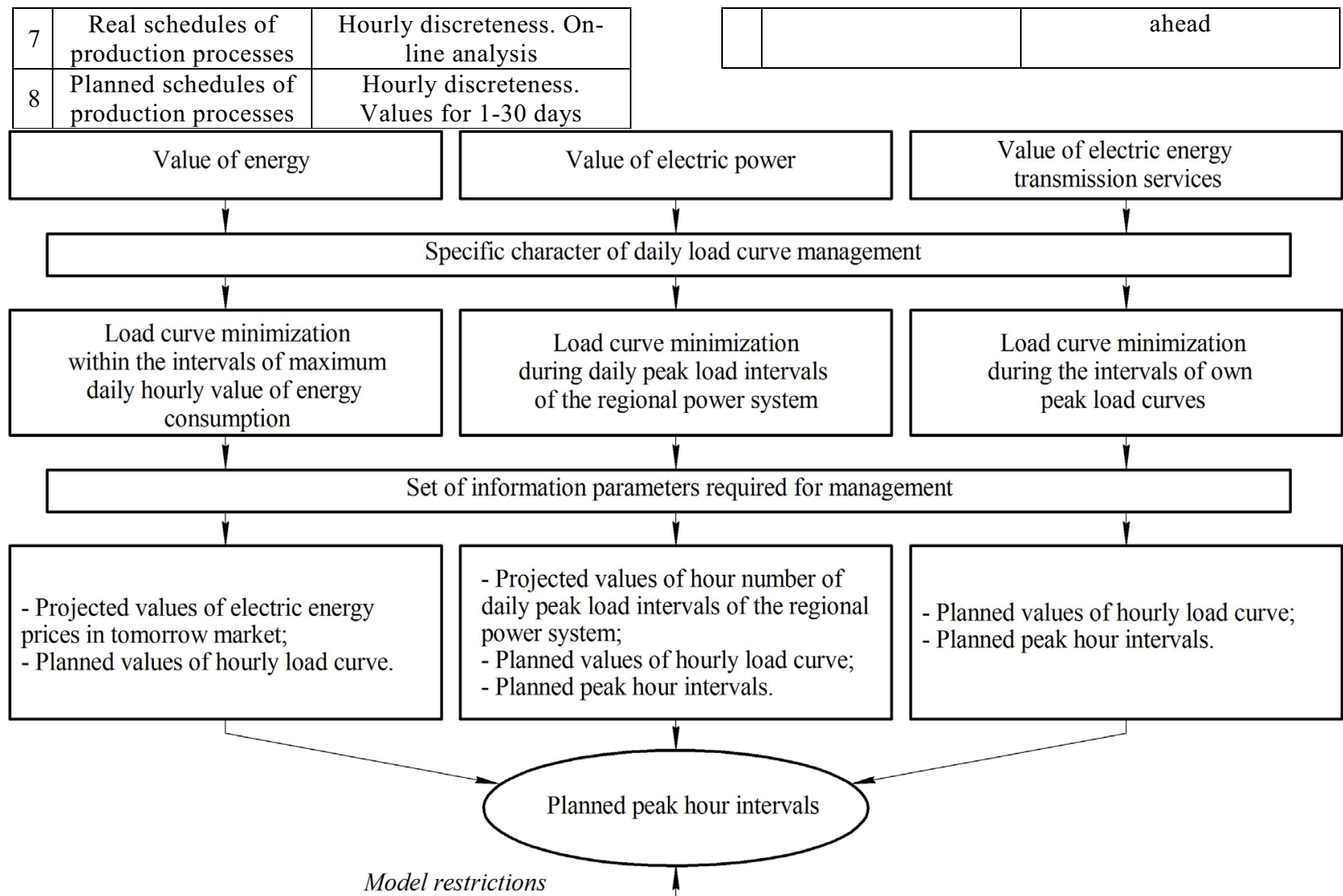

Model restrictions

Shift of production processes schedules:

- Technological possibility;

- Economic expediency.

Fig. 5. Model of price-dependent management of industrial enterprise electric energy consumption.

Practical significance and timeliness of the offered method of electric energy consumption cost management is stressed by its practical approval carried out by the authors at iron and steel companies OJSC "Ogneupory" (town of Bogdanovich, the Sverdlovsk region) and CJSC "Volgogradskiy metallurgicheskiy zavod "Krasniy Oktyabr" (city of Volglgrad).

Practical approval revealed that cost saving in terms of electric energy component can reach $20 \%$ to $50 \%$ of the value before management effect. As for costs of electric power component its cost saving can range from $7 \%$ to $50 \%$ of

electric power cost [19]. Costs of transmission services component can be cut down by 5-20\%. Thus, practical approval clearly demonstrates that it's possible to lower costs in terms of all its elements, keeping in mind their shares in the structure of costs, by $10 \%-40 \%$ of aggregate value of electric energy costs; real terms may be as big as several million rubles per annum.

\section{Conclusion}

The research conducted leads to a number of important conclusions. Present-day wholesale and retail energy markets make it possible for industrial enterprises through introducing price-dependent energy consumption management to cut down by themselves their costs incurred by buying electric energy.
Application of the developed model of price-dependent energy consumption management allows complex management of all existing energy consumption cost components, resulting in substantial economic enterprise-wide effect. The model of price-dependent management should be introduced based on substantial volume of information and take into consideration specific features of production facilities and processes. The scale of the economic effect caused by the implementation of the model offered emphasizes its scientific and practical significance.

The work was supported by Act 211 Government of the Russian Federation, contract № 02.A03.21.0011

\section{References}

1. The Law on the US national energy saving policy. http://www.encyclopedia.com/doc/1G23407400214.html

2. Energy Conservation and Demand Management Program. Queensland Government. Queensland Government, n.d. Web, 2010. http://www.climatechange.qld.gov.au/pdf/factshe ets/1 energy-b1.pdf

3. H. Haeri, L. Gage, T. Jayaweera, Assessment of Long-Term, System-Wide Potential for DemandSide and Other Supplemental Resources. 
http://www.pacificorp.com/content/dam/pacificor p/doc/Energy_Sources/Demand_Side_Manageme nt/Demand_Side_Management.pdf

4. International Energy Agency Demand Side Management Energy Efficiency. http://www.ieadsm.org/

5. Pacificorp demand-side resource potential assessment for 2015-2034, PacifiCorp, vol. 1-5. http://www.pacificorp.com/es/dsm.html.

6. J. Torriti, Peak Energy Demand and Demand Side Response,

2016. https://www.book2look.com/embed/97813177044 7.

7. L.D. Gitelman, B.E. Ratnikov, M.B. Kozhevnikov, Yu.P. Shevelev, Energy demand side management. Unique innovation for Russian power industry: monograph (Yekateinburg, 2013)

8. L.D. Gitelman, B.E. Ratnikov, M.V. Kozhevnikov, "Demand-side management: adaptation of foreign experience to Russian conditions," Effective Crisis Management, 2013. http://info.e-c-

m.ru/magazine/76/eau_76_207.htm.

9. L.D. Gitelman, B.E. Ratnikov, Economics and Business in the Electrical Energy Industry: crossdisciplinary manual (Economics, Moscow, 2013)

10. I.A. Baev, I.A. Solovyova, A.P. Dzyuba, Siberia Science Bulletin, 49(19) (2015) http://sjs.tpu.ru/journal/article/view/1406/968.

11. RF Government Decree no. 1172 of 27 December, 2010. www.government.consultant.ru.
12. RF Government Decree no. 442 of 04 May, 2012. www.government.consultant.ru/.

13. Official Website of OJSC. http://www.atsenergo.ru/.

14. I.A. Solovyova, A.P. Dzyuba, Bulletin of the South Ural state university. Series: Economics and management, 23, 30(289), 116-123 (2012)

15. I.A. Solovyova, A.P. Dzyuba, Bulletin of the South Ural state university. Series: Economics and management, 7, 3, 47-57 (2013)

16. I.A. Baev, A.P. Dzyuba, Regional Economy, 4, 109-116 (2012)

17. Official Website of Non-Commercial Partnership. www.np-sr.ru.

18. Official Website of OJSC. http://so-ups.ru/.

19. I.A. Baev, I.A. Solovyova, A.P. Dzyuba, Economics, management and investment, 2(4) (2014). http://euii-journal.ru/24-43.

20. A.P. Dzyuba, Proc. Energy saving, information technologies and sustainable development: International scientific and practical online conference, 35-42 (2014)

21. I.A. Solovyova, A.P. Dzyuba, Proc. Problems of ensuring safe development of contemporary society, 47-57 (2014)

22. A.P. Dzyuba, I.A. Baev, I.A. Solovyova, L.D. Gitelman, Energy: Challenges and Solutions WIT Transactions on Ecology and the Environment, 212, 105-114 (2015)

23. Official Website of Public Joint Stock Company. http://www.rosseti.ru/. 